\title{
Archive
}

Research Letter

\section{Is Hydroxychloroquine Safe During Pregnancy? Observations from Penn Medicine}

Lena Davidson ${ }^{1}, \mathrm{MS}$, Silvia P. Canelón ${ }^{1}, \mathrm{PhD}$, Mary Regina Boland ${ }^{1}$, MA, MPhil, PhD, FAMIA

${ }^{1}$ Department of Biostatistics, Epidemiology and Informatics, Perelman School of Medicine, University of Pennsylvania

Word Count: 389

Reference Count: 5

\section{Figures: 1}

Submitted Manuscript Date: March 29, 2020

\section{Corresponding Author:}

Mary Regina Boland, PhD

Assistant Professor of Informatics

Perelman School of Medicine

University of Pennsylvania

423 Guardian Drive,

421 Blockley Hall

Philadelphia, PA 19104

Email: bolandm@upenn.edu 
medRxiv preprint doi: https://doi.org/10.1101/2020.04.29.20085621; this version posted May 6, 2020. The copyright holder for this preprint

(which was not certified by peer review) is the author/funder, who has granted medRxiv a license to display the preprint in perpetuity.

All rights reserved. No reuse allowed without permission.

A novel strain of coronavirus appeared in December 2019. Over the next few months, this novel coronavirus spread throughout the world, being declared a pandemic by the World Health Organization on March 11, 2020. As of this writing (March 28, 2020) over one hundred thousand individuals in the United States of America were confirmed cases. One way of treating the associated disease, COVID-19, is to reuse existing FDAapproved medications. One medication that has shown promise is hydroxychloroquine (HCQ). However, the utility and safety of HCQ among pregnant COVID-19 patients remains a concern.

A recent open-label non-randomized clinical trial of HCQ and azithromycin as treatment for COVID-19 excluded pregnant and breastfeeding patients from the study[1]. HCQ is considered a Category $\mathrm{C}$ medication, indicating that it remains unknown what effect the drug will have on the fetus.

There is evidence that HCQ may be safe during pregnancy, with previous research finding no increased risk of, prematurity, fetal death, retinopathy, low birth weight, stillbirth, or congenital defects[2-4]. However, there is also evidence that HCQ could result in fetal harm with a recent meta-analysis finding an association between HCQ use and spontaneous abortion ${ }^{3}$ and small for gestational age[5]. Therefore, clinicians may be faced with the difficult decision of deciding whether to treat their pregnant COVID-19 patients with HCQ.

At Penn Medicine, we have pregnancy outcomes following 63,334 deliveries between 2010 and 2017 with the following outcomes annotated: Caesarean section delivery, preterm birth, multiple birth (e.g., twins, triplets) and stillbirth. We assessed whether there was an increased risk of any of these four outcomes following exposure to HCQ during pregnancy where exposure was determined to occur between 280 days (i.e., 40 weeks) and up to 1 day prior to the date of delivery. The Institutional Review Board at the University of Pennsylvania approved this study. We found that 28 deliveries had documented HCQ exposure, results shown in Figure. We did not find increased risk for any of the four measured outcomes ( $p>0.05)$ : Caesarean Section, Preterm birth, Multiple birth, and Stillbirth. We also expanded our search to include all quine drugs (i.e., HCQ, primaquine, mefloquine, chloroquine phosphate) and found the same negative result (i.e., no increased risk).

Our findings coupled with some of those in the literature[2-4] suggest that HCQ may not adversely affect fetal outcomes when taking HCQ during pregnancy. Therefore, clinicians may consider including pregnant patients with COVID-19 in clinical trials of HCQ when warranted. 
medRxiv preprint doi: https://doi.org/10.1101/2020.04.29.20085621; this version posted May 6, 2020. The copyright holder for this preprint (which was not certified by peer review) is the author/funder, who has granted medRxiv a license to display the preprint in perpetuity. All rights reserved. No reuse allowed without permission.

\section{CONFLICTS OF INTEREST}

The authors report no conflicts of interest.

\section{FUNDING}

This work was funded by the generous support of the University of Pennsylvania, Perelman School of Medicine.

\section{IRB APPROVAL \#828000}

\section{REFERENCES}

[1] Gautret P, Lagier J-C, Parola P, Meddeb L, Mailhe M, Doudier B, et al. Hydroxychloroquine and azithromycin as a treatment of COVID-19: results of an open-label non-randomized clinical trial. International Journal of Antimicrobial Agents. 2020:105949.

[2] Kaplan YC, Ozsarfati J, Nickel C, Koren G. Reproductive outcomes following hydroxychloroquine use for autoimmune diseases: a systematic review and meta - analysis. British journal of clinical pharmacology. 2016;81:835-48.

[3] Cooper WO, Cheetham TC, Li DK, Stein CM, Callahan ST, Morgan TM, et al. Brief report: Risk of adverse fetal outcomes associated with immunosuppressive medications for chronic immune - mediated diseases in pregnancy. Arthritis \& Rheumatology. 2014;66:444-50.

[4] Sperber K, Hom C, Chao CP, Shapiro D, Ash J. Systematic review of hydroxychloroquine use in pregnant patients with autoimmune diseases. Pediatric Rheumatology. 2009;7:9.

[5] Howren A, Rebić N, Sayre E, Tsao N, Amiri N, Baldwin C, et al. Perinatal exposure to conventional synthetic disease-modifying anti-rheumatic drugs in women with rheumatic disease and neonatal outcomes: a population-based study. Clinical and experimental rheumatology. 2020. 
medRxiv preprint doi: https://doi.org/10.1101/2020.04.29.20085621; this version posted May 6, 2020. The copyright holder for this preprint (which was not certified by peer review) is the author/funder, who has granted medRxiv a license to display the preprint in perpetuity.

All rights reserved. No reuse allowed without permission.

Hydroxychloroquine Exposure During Pregnancy

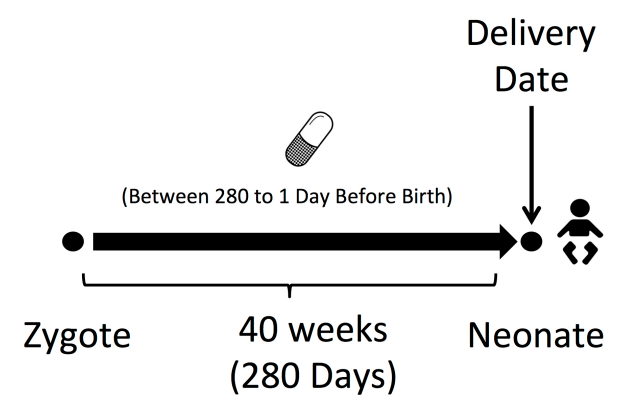

Hydroxychloroquine Exposure and Pregnancy Outcomes

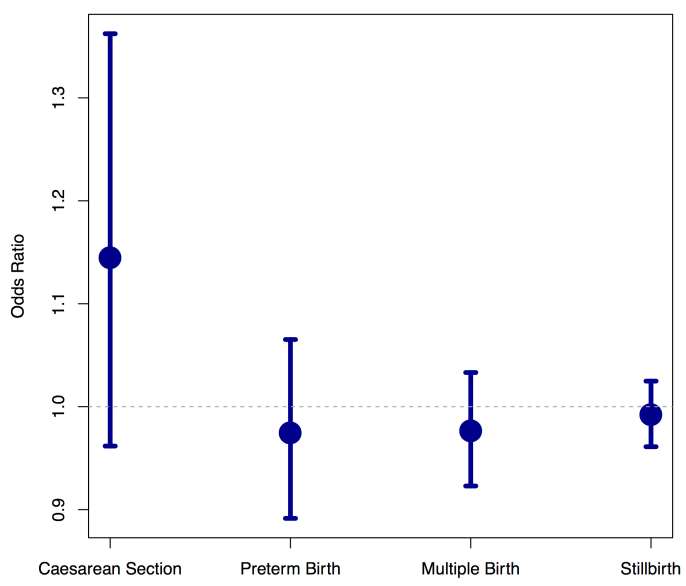

Delivery Characteristics of Patients that Delivered at Penn Medicine

\begin{tabular}{l|lll}
\hline Demographics & $\begin{array}{l}\text { All Deliveries } \\
\text { (N=63,334 } \\
\text { Deliveries) }\end{array}$ & $\begin{array}{l}\text { Exposure to Any } \\
\text { 'quine' Drug } \\
\text { (N=47 Deliveries) }\end{array}$ & $\begin{array}{l}\text { Exposure to } \\
\text { Hydroxychloroquine } \\
\text { (N=28 Deliveries) }\end{array}$ \\
\hline Race/Ethnicity & & & \\
Non-Hispanic Black or African American & $29965(47.3 \%)$ & $16(34.0 \%)$ & $14(50.0 \%)$ \\
Non-Hispanic White & $21443(33.9 \%)$ & $21(44.7 \%)$ & $9(32.1 \%)$ \\
$\quad$ Other & $12166(19.2 \%)$ & $10(21.3 \%)$ & $5(17.9 \%)$ \\
\hline Age, years (avg. \pm standard deviation) & $29.48 \pm 6.08$ & $32.31 \pm 4.35$ & $31.13 \pm 4.53$ \\
\hline
\end{tabular}

Figure. Hydroxychloroquine Exposure and Four Delivery Outcomes (Caesarean Section, Preterm Birth, Multiple Birth, Stillbirth) Using PennMedicine Data from 28 Pregnancies 